\title{
Social retfærdighed og økonomiske incitamenter Om systemkritik og moraliseren i venstreorienteret politisk teori
}

\author{
Christian F. Rostbøll \\ Lektor, Institut for Statskundskab, Københavns Universitet
}

Bør man som venstreorienteret acceptere, at det er nødvendigt at belønne dem, der arbejder og yder en ekstra indsats? Eller bør venstreorienterede ikke nærmere kritisere den grådighed, der lægger bag kravet om økonomiske incitamenter? Denne artikel ser på, hvad en gren af den politiske filosofi kan bidrage med i diskussionen af disse spørgsmål.

\section{Indledning}

Skal venstrefløjen først og fremmest varetage arbejderklassens interesser, eller skal dens mål være at skabe mere lighed i samfundet? Skal venstreorienteret politisk teori begrænse sig til systemkritik, eller bør den også opstille retfærdighedsprincipper, hvormed den kan kritisere borgernes personlige valg? Når S-R-SF-regeringen i 2012 laver en skattereform, som ifølge den daværende skatteminister Thor Möger Pedersen (SF) er til de „hårdtarbejdende lønmodtagere“ og har som mål, ,at det i højere grad end i dag skal kunne betale sig at tage et arbejde" (Pedersen 2012), så retfærdiggøres en vis ulighed til fordel for dem, der har arbejde. En vis ulighed accepteres på samme vis, når en selverklæret repræsentant fra arbejderklassen roser Möger Pedersen for at gøre op med „nødhjælpssocialisterne ... Et velmenende flertal, der er i politik for at dele ud af deres barmhjertighed til kontanthjælpsmodtagere, miljøet, de fattige studerende, ja faktisk til hele verden“" (Skovhus 2012). To forhold sammenkobles i dette syn på venstreorientering, nemlig at ,arbejderpartierne utvetydigt skal tjene arbejdernes interesser" (Skovhus 2012), og at dette kræver, at dem $i$ arbejde får mere end folk på kon- tanthjælp. Udgangspunktet for denne artikel er, at valget mellem at sikre, at det skal kunne betale sig at arbejde, på den ene side og hensynet til ligheden på den anden side, er et principielt valg - et valg, som kræver, at man klargør, hvilke moralske principper der er på spil, og hvilken vægt de bør have. Det er derudover et spørgsmål, som berører, hvorvidt en venstreorienteret politisk teori skal holde sig til systemkritik, eller om den også bør kritisere folks personlige valg ud fra moralske principper.

Den marxistiske venstrefløj har traditionelt holdt sig væk fra at kritisere de valg, borgerne tager, og de motiver, de har som deltagere i det kapitalistiske marked. For eksempel siger den tidligere VS-politiker Preben Wilhjelm $i$ et interview om sit syn på den finanskrise, der begyndte i 2008, at det er et udtryk for "moraliseren“ at lægge skylden på grådige banker: „Hvad havde man tænkt sig skulle være styrende for kapitalens dispositioner, om ikke grådigheden? Det er jo latterligt at forestille sig et kapitalistisk system, der ikke er baseret på grådighed - eller pænere formuleret: størst muligt afkast ... Derfor har vi ikke brug for moraliserende pegefingre, men for systemkritik" (Jespersen 2012). En tilsvarende holdning finder man hos Tysklands vigtigste venstreintellektuelle tænker og filosof, Jürgen Habermas (2009, 184): "The speculators, too, were acting consistently within the established legal framework, according to the socially recognized logic of profit maximization. Politics turns itself into a laughing stock when it resorts to moralizing instead of relying upon the enforceable law of the democratic legislator." Venstreintellektuelles afstandtagen fra moraliseren kan bygge enten på, at moralske domme ikke bør rette sig (direkte) mod markedsaktørers valg og motiver, eller den 
kan være baseret på en afvisning af relevansen af moralsk kritik overhovedet. Det første kan være et resultat af en accept af, at marked og politik bygger på forskellige logikker (hvilket er tilfældet hos Habermas; se Rostbøll 2011, $37 \mathrm{ff}, 59 \mathrm{ff})$. Det andet kan bygge på den opfattelse, at moral blot er borgerlig ideologi og et overfladefænomen, som dækker over det virkelige, som er livets materielle basis og produktionsforholdene (Marx 2000 [1845/46]).

Moraliseren kan forstås enten bredt som enhver kritik baseret på moral, eller mere snævert som moralsk kritik af borgernes private valg. Systemkritik kan enten være baseret på moralske principper (som når man hævder, at det kapitalistiske system er uretfærdigt), eller den kan være baseret på en moralsk neutral analyse (som Karl Marx mente, at hans historiske materialisme var og konkluderede, at det kapitalistiske system er selvundergravende). I det følgende skal vi se på alle fire muligheder som fokus for en venstreorienteret politisk teori, dvs. på begge former for moraliseren, bred og snæver, og begge former for systemkritik, moralsk baseret og moralsk neutral.

Ønsket om at undgå moraliseren bredt forstået har haft den konsekvens, at marxistiske teoretikere har været tilbageholdende med at udvikle en egentlig retfærdighedsteori. Marxister har frygtet at fremføre en kritik af eksisterende samfund, som blot er „ideologisk“, og har desuden ment, at moralsk kritik var unødvendig, da det kapitalistiske samfund er selvundergravende (Cohen 2000, 101ff). I kontrast til marxisters forbeholdenhed i forhold til at tale om moral står den omfattende filosofiske diskussion af retfærdighed blandt liberale egalitarister, der fulgte i kølvandet på John Rawls' A Theory of Justice fra 1971 (Rawls 1999). Inden for denne diskussion i særligt anglo-saksisk politisk filosofi ses moral og retfærdighedsprincipper almindeligvis ikke som overfladefænomener, men derimod som noget, der kan supplere standarder, hvormed eksisterende politiske og økonomiske systemer kan vurderes og kritiseres. Hos Rawls er hensigten med retfærdighedsprincipperne ikke at ændre hele vores mentalitet, men derimod at opstille principper for det velordnede samfunds grundlæggende struktur (Rawls 1999, 6ff). Ifølge Rawls er det ikke påkrævet, at alle personlige valg er taget med respekt for retfærdighedsprincipperne, så længe samfundets grundlæggende struktur er retfærdig (Cohen 2008, 2).

Denne artikel præsenterer og diskuterer nogle centrale argumenter hos den politiske filosof G.A. Cohen, som har bidraget med en vigtig venstrekritik af Rawls i værker som If You're an Egalitarian, How Come You're So Rich? (2000) og Rescuing Justice and Equality (2008). Cohen argumenterer bl.a. for, at et mere lige samfund ikke kan realiseres udelukkende gennem strukturændringer, men at der også er behov for en mentalitetsændring og et egalitert etos (dvs. et sæt af egalitære værdier, der motiverer borgerne i deres hverdag). Ifølge Cohen ser vi behovet for et egalitært etos særligt i forhold til den udbredte idé, at økonomisk ulighed kan retfærdiggøres, fordi det giver incitamenter til at arbejde og gøre en ekstra indsats, hvilket skulle være til alles fordel: Den politiske teori kan ikke kritisere dette incitamentsarguments retfærdiggørelse af økonomisk ulighed, hvis den kun forholder sig til den grundlæggende struktur og freder borgernes personlige valg.

Indeværende artikel argumenterer for, at venstrefløjen har behov for at klargøre og begrunde, hvilke retfærdighedsprincipper den kæmper for. På baggrund af en præsentation af centrale argumenter hos Cohen og en påpegning af deres relevans i forhold til den danske offentlige debat diskuteres det endvidere, om disse principper er nogle, der udelukkende bør regulere samfundets grundlæggende struktur, eller om de også bør blive en del af et retfærdigt samfunds etos, dvs. om retfærdighedsprincipperne også bør styre vores personlige valg. Denne diskussion vil fokusere på incitamentsargumentet, som siger, at $ø$ konomiske uligheder er acceptable, fordi de gør de mest talentfulde mere produktive og dermed bidrager til, at alle får det bedre, også de mindst begunstigede. Incitamentsargumentet ser ud til at være bredt accepteret i den offentlige debat og blandt politiske filosoffer, men Cohen fremfører et vægtigt argument imod denne konsensus om, at det er nødvendigt og til alles gavn at belønne folk for at arbejde eller gøre en ekstra indsats.

Fokusset på økonomiske incitamenter, lighed, systemkritik og moraliseren, skal ikke ses som et udtryk for, at dette er de eneste vigtige spørgsmål for en venstreorienteret politisk teori. Dette fokus er affødt af en aktuel debat i den danske offentlighed og af en centrum-venstreregering, der har accepteret ideen om, at en vis ulighed til fordel for dem i arbejde er acceptabel. Artiklen fokuserer på Rawls' retfærdighedsteori og Cohens kritik af denne, fordi disse teoretikere eksplicit udvikler retfærdighedsprincipper og relaterer deres anvendelse til spørgsmål om økonomiske incitamenter, lighed, samfundets grundlæggende struktur og borgernes personlige valg. Argumentet $i$ artiklen er ikke, at det lige præcis er Rawls' retfærdighedsprincipper, venstrefløjen skal acceptere. Argumentet er derimod, at venstrefløjen har behov for at diskutere retfærdighedsprincipper og for at overveje, hvorvidt disse principper kun bør anvendes i en kritik af samfundets grundlæggende struktur eller også i en kritik af borgernes personlige valg. Formålet med det følgende er dermed at rejse nogle spørgsmål for venstrefløjen, som er systematisk behandlet $\mathrm{i}$ en bestemt del af den normative politiske filosofi - og ikke at insinuere, at der ikke er andre vigtige spørgsmål for venstrefløjen eller andre vigtige bidrag til venstrefløjstænkningen i den politiske teori og filosofi. 
Artiklen begynder med en diskussion af fraværet af en retfærdighedsteori i marxismen og behovet for en sådan på venstrefløjen (II og III). Derefter gives en kort præsentation af Rawls' retfærdighedsteori og Cohens kritik af den (IV). I afsnit $\mathrm{V}$ fremlægges kritikken af incitamentsargumentet. Artiklens sidste afsnit (VI) før konklusionen diskuterer forholdet mellem systemkritik og behovet for et egalitært etos.

\section{II. „Sådan er kapitalismen“ - Marxisme og retfærdighed}

I 1970'erne og 1980'erne var der en vigtig diskussion blandt politiske teoretikere og filosoffer om, hvorvidt Marx anså kapitalismen for uretfærdig (Geras 1985; 1992; Roemer 1986, Part IV; Wood 1972). Nogle vil måske sige, at selvfølgelig anså Marx kapitalismen for uretfærdig: han var dens vigtigste kritikker. Men Marx skrev faktisk eksplicit, at man ikke kan kalde kapitalistisk udbytning for uretfærdig (Marx 1990 [1867], 310). Kommentatorerne er enige om, at Marx fordømte kapitalismen, men de er uenige om, hvorvidt han fordømte kapitalismen som uretfardig. Og der er en stor forskel på, om Marx blot mente, at kapitalismen var selvmodsigende og selvundergravende - hvilket der er enighed om, at han gjorde - eller om han også mente, at kapitalismen kunne kritiseres ud fra (rationelt begrundede) retfærdighedsprincipper - hvilket er det, den omtalte kontrovers vedrører.

For denne artikels formål er det ikke afgørende, hvem der har ret i deres fortolkning af Marx. Den rigtige fortolkning er muligvis den paradoksale forslået af Norman Geras (1985, 70): "Marx did think that capitalism was unjust but he did not think he thought so." Det afgørende her er, at Marx' værker åbner op for denne usikkerhed om, hvorvidt han mener, at kapitalismen er uretfærdig. Det er min opfattelse, at denne ambivalens har påvirket venstrefløjen pga. dens marxistiske rødder. På den ene side anser venstrefløjen kapitalismen med dens udbytning af arbejderne for problematisk, men på den anden side er den skeptisk over for at tale om retfærdighed og uretfærdighed. I hvert fald kan man sige, at Marx' synspunkt og indflydelse har været med til at modvirke udviklingen af en egentlig retfærdighedsteori på venstrefløjen. Venstrefløjen har måske nok talt om social retfærdighed og lige muligheder, men den savner en systematisk retfærdighedsteori.

Den marxistiske ambivalens i forhold til at tale om retfærdighed har ikke blot betydet et fravær af en socialistisk retfærdighedsteori, men også fravær af moralsk kritik af markedsaktørers motiver og valg. Som jeg citerede Wilhelm for, anses det for latterligt at forestille sig et kapitalistisk system, som ikke er baseret på grådighed. Men hvorfor? Der er (mindst) to mulige svar: Enten er det, fordi kapitalismen som system ikke kan fungere uden profitmaksimeringsmotivet (grådigheden), eller også er det, fordi grådigheden er et produkt af den kapitalistiske produktionsmåde og kun kan ophæves ved en revolutionær ændring af produktionsmåden. Det første svar bygger på en accept af Adam Smiths antagelse om, at markedssamkvem bygger på egeninteresse (Smith 2000, 15) Det andet bygger på en idé om, at den menneskelige egoisme ikke er et grundvilkår eller en del af den menneskelige natur, men derimod er et produkt af kapitalismen. Men uanset om det ene eller det andet svar er det rigtige, så er konsekvensen, at man ikke kan kritisere egoismen under kapitalismen. „Sådan er kapitalismen“, som det lyder i en sang, som alle på den danske venstrefløj kender.

Spørgsmålet er, om venstrefløjen ikke mangler noget vigtigt, hvis den ikke har en retfærdighedsteori. Har venstrefløjspartier og -bevægelser ikke behov for at klargøre, hvilke principper der guider dens projekter? Har de ikke brug for standarder, som kan lægges til grund for deres kritik af det eksisterende system? Med andre ord, har systemkritikken ikke behov for et moralsk grundlag? Og er der ikke behov for en moralsk kritik, der går videre end systemkritikken og retter sig mod de valg, som vi tager som privatpersoner? Hvis svaret på nogle af disse spørgsmål er ,ja“, så er der god grund til at gøre op med den marxistiske skepsis over for at tale om retfærdighed og moral. Dette er ikke et opgør med marxismen tout court, men derimod et spørgsmål om at klargøre, udvikle og begrunde den implicitte tro på værdien i et mere lige samfund, som animerede Marx' kritik af kapitalistisk udbytning (Cohen 2000, x).

\section{Behovet for en retfærdighedsteori}

Cohen $(2000,42-115)$ deler den marxistiske tro på værdien $i$ et mere lige samfund, men han argumenterer, at det er en stor svaghed ved marxismen, at den mangler systematisk normativ refleksion, præcisering af idealer og principper, afvejning af forskellige normative hensyn og begrundelse af retfærdighedsprincipper. Denne mangel ved marxismen er særligt graverende, da det har vist sig, at Marx' optimisme i forhold til kapitalismens selvundergravende karakter og socialismens uundgåelige sejr har vist sig at være en illusion. Det er med andre ord den videnskabelige socialismes fallit, som er baggrunden for, at Cohen mener, at socialister har behov for at engagere sig i systematisk normativ refleksion og begrundelse af retfærdighedsprincipper. Da det har vist sig, at kapitalismen ikke dialektisk opløser sig selv indefra, som Marx troede den ville, så er der ifølge Cohen behov for retfærdighedsprincipper, på baggrund af hvilke kapitalismen kan kritiseres udefra.

På den danske venstrefløj ved man ikke, hvilket ben man skal stå på, når velfærdsstaten bliver kritiseret for at 
give for høje overførselsindkomster og/eller støtte kontanthjælpsmodtagere, som ikke gider at arbejde. Da det i 2011 kom frem, at en kontanthjælpsmodtager, „Fattig Carina“, ikke var så fattig, som mange havde troet, stillede repræsentanter for alle venstrefløjspartier op og bedyrede, at de skam også mente, at det skulle kunne betale sig at arbejde. ${ }^{1}$ Tilsvarende var der året efter ingen på venstrefløjen, der kunne eller ville forsvare „Dovne Robert", der havde levet på kontanthjælp i årevis og afvist at tage imod en række jobtilbud. ${ }^{2}$ Endelig kan opgøret i SF, der er i 2012 førte til formandsskift, nævnes. Kort sagt handlede konflikten om, hvorvidt SF er et parti, der først og fremmest har som mål at beskytte de lavtlønnede arbejderes interesser (dem i kedeldragt, dem der står op hver morgen og smører leverpostejmadder, som Thor Möger Pedersen [2012] beskrev dem), eller om partiet har et bredere ansvar for at sikre alle svage gruppers behov. Jeg vil hævde, at alle disse er eksempler på venstrefløjens usikkerhed på egne principper. Folk på den danske venstrefløj er ofte både ude af stand til normativt at forsvare den omfordeling af ressourcerne, som velfærdssten indebærer, og de mangler principper, der kan bidrage til at afveje forskellige normative hensyn.

Med Cohen kan vi forstå venstrefløjens usikkerhed på egne principper på baggrund af et problem ved Marx’ immanente kritik af kapitalismen generelt og hans klasseteori i særdeleshed. ${ }^{3}$ I Marx' analyse er det én klasse, der lider alle afsavnene. Det er proletariatet, der bliver udbyttet, som er ufrie, og hvis behov ikke tilfredsstilles. Desuden udgør arbejderklasen det store flertal af befolkningen. Denne situation, som var gældende i det 19. århundredes mest udviklede kapitaliske industrisamfund, kan kritiseres ud fra en række forskellige moralteorier og med forskellige retfærdighedsprincipperne. At flertallet lider afsavn, kan kriseres ud fra utilitarismens princip om nyttemaksimering: Nytten i samfundet maksimeres næppe i et samfund, hvor de få besidder alle goderne. Udbytning kan kriseres ud fra et princip om, at man fortjener frugterne af sit arbejde: Et problem ved kapitalismen er, at arbejdets merværdi går til en anden (kapitalisten) end den, der har produceret den (arbejderen) (Marx 1990 [1867], Del III). Marx bekriver endvidere proletariatet som lønslaver og appellerer dermed til end nu et normativt princip, nemlig frihed. Endelig er det et kritikpunkt ved kapitalismen, at den forarmer arbejderklassen, hvormed der appelleres til et princip om behovstilfredsstillelse eller måske lighed. Hvis Marx' klasseteori var gyldig, ville der være et sammenfald mellem disse normative principper, og det er måske derfor, at marxister ikke har følt et behov for at afveje de forskellige normative principper op imod hinanden eller diskutere, hvilke der er vigtigst. Problemet er, ifølge Cohen (2000, 105ff), at klasseteorien ikke er gyldig længere. Proletariatet, som Marx definerede det, udgør ikke længere flertallet, og det er ikke længere den samme gruppe mennesker, der bliver udbyttet og som lider under fattigdom. I dag opstår derfor særligt en konflikt mellem hensynet til dem, der bliver udbyttet, og dem, der lider de værste materielle afsavn. Det er denne konflikt, som i SF går mellem hensynet til dem i kedeldragt og de svage uden for arbejdsmarkedet (inkl. asylansøgere, immigranter og fattige $i$ andre lande). For Cohen er dette en konflikt mellem et fortjenestesprincip og et lighedsprincip.

Når det ikke længere er den samme gruppe i samfundet, der bliver udbyttet, og som lider de værste materielle afsavn, og når hensynet til dem, der producerer værdien $\mathrm{i}$ samfundet, kommer i konflikt med hensynet til ligheden, så er der behov for, at socialister ikke begrænser sig til den materialistiske analyse af produktivkræfter og produktionsforhold, men også engagerer sig i normativ politisk filosofi (Cohen 2000, 108f). Grunden er for det første, at venstrefløjen har brug for en retfærdighedsteori, som kan bidrage til afvejningen af, hvilke principper der er vigtigst. For det andet kan socialister ikke længere blot appellere til arbejderklassens interesser, da proletariatets interesser ikke nødvendigvis er sammenfaldende med almenvellet. Der er derfor behov for moralske argumenter for et mere lige samfund. Endelig skal det med, at frem for Marx' forudsigelse om fremtidig overflod, som ville gøre omfordeling unødvendig, står verden i dag over for økologisk krise og økonomisk knaphed, hvilket gør det endnu mere påkrævende med principper for, hvordan knappe ressourcer skal fordeles på en retfærdig måde (Cohen 2000, 112ff).

Problemet med marxismen er, ifølge Cohen, at den bygger på en illusion om, at bare vi forstår problemets karakter, vil løsningen også give sig selv. Det er den samme illusion, der ligger bag tanken om, at „videnskabelig“ eller moralsk neutral systemkritik er tilstrækkelig: Hvis vi bare analyserer kapitalismens indre modsætninger, lyder illusionen, er der intet behov for at begrunde eller overveje, hvilke principper der bør regulere samfundet efter kapitalismens sammenbrud. Dette er en farlig holdning, bl.a. fordi socialister dermed ikke giver begrundelser for de moralske principper, der guider deres projekt, og mangler klare og velbegrundede principper, som kan bidrage til at løse normative dilemmaer. Mere præcist er problemet, at venstrefløjen ikke er tilstrækkelig bevidst om de principper, der implicit styrer deres politiske handling, og derfor ikke systematiserer og begrunder dem, og at den mangler teoretiske og moralske ressourcer til systematisk at afveje forskellige normative hensyn som for eksempel hensynet til arbejderklassens interesser over for hensynet til de arbejdsløse, asylansøger, immigranter og verdens fattige. 


\section{Cohen vs. Rawls}

Systematisk normativ refleksion, præcisering af retfærdighedsprincipper og moralske argumenter for et mere lige samfund finder vi mest indflydelsesrigt i nutidens politiske filosofi hos John Rawls. Da Rawls udgav $A$ Theory of Justice, blev den af en britisk kommentator fejret som "a noble coherent, highly abstract picture of the fair society, as social democrats see it ... [The Labor Party] needed just such a theory of justice as this, stated in its full philosophical generality" (Stuart Hampshire, citeret i Wolff 2012, 152). Selv om Cohen er dybt påvirket af Rawls, mener han, at der er et grundlæggende problem ved den måde, som Rawls konstruerer sin retfærdighedsteori på. Mere præcist er Cohen kritisk over for, at Rawls mener, at retfærdighedsprincipperne kun skal gælde samfundets grundlæggende struktur og ikke bør anvendes på borgernes private valg.

Vi kan ikke her gå nærmere ind i Rawls' retfærdighedsteori, men må begrænse os til hans „forskelsprincip“ og dets applicering. Forskelsprincippet er et centralt element i Rawls’ teori og lyder som følger: „Sociale og økonomiske uligheder skal indrettes således, at de ... er ... til den størst mulige gavn for de mindst begunstigede“ (Rawls 2005, 296). Det vil sige, at hos Rawls er forbedring af de mindst begunstigedes situation det eneste, der kan retfærdiggøre ulighed. Ulighed kan for eksempel ikke begrundes med, at de rige har fortjent deres rigdom pga. deres flid eller dygtighed. Kun hvis ulighed er til gavn for de mindst begunstige, kan den normativt begrundes også over for de mindst begunstige, da den sidstnævnte gruppe selv har gavn af uligheden, mener Rawls. Cohen afviser ikke forskelsprincippet som sådant, men kun den fortolkning og applicering af det, som kan bruges til at forsvare ulighedsskabende incitamenter (Cohen 2008, 32). Det er et velkendt argument fra den offentlige debat, at økonomiske incitamenter (og dermed en vis ulighed) er nødvendige for at få folk til at arbejde og gøre en ekstra indsats, og at dette er til alles bedste, også de mindst privilegeredes. Dette argument ser ud til at være foreneligt med forskelsprincippet: Hvis ulighed sikrer økonomiske incitamenter, der fremmer produktiv flid, som stiller de mindst begunstige bedre end uden ulighed, så ser denne ulighed ud til at være retfærdig ifølge forskelsprincippet. Cohen tilbageviser denne applicering af forskelsprincippet og viser grundlæggende problemer ved det udbredte incitamentsargument.

Som nævnt er det et helt afgørende aspekt ved Rawls' teori, at de retfærdighedsprincipper, han udleder, kun gælder for samfundets grundlæggende struktur: "For us the subject of justice is the basic structure of society, or more exactly, the way in which major social institutions distribute fundamental rights and duties and determine the division of advantages from social cooperation" (Rawls 1999, 6). Det er ikke helt ligetil at afgrænse præcist, hvad der udgør samfundets grundlæggende struktur, men i vores sammenhæng er det afgørende, at denne afgrænsning for Rawls betyder, at forskelsprincippet $i k k e$ kan anvendes i en kritik af markedsaktørers valg: Så længe strukturen regulereres i henhold til retfærdighedsprincipperne, behøver aktørerne i deres private valg ikke at bekymre sig om de dårligst stilledes kår (jf. Rawls 1999, 82).

Rawls' afgrænsning af retfærdighedsprincippernes domæne til den grundlæggende struktur medfører, at hans teori tillader mere ulighed, end den burde gøre ifølge Cohen. I forhold til vores tidligere nævnte eksempel med bank- og finansfolk beklager Cohen (2000, 123), at Rawls ikke applicerer sit sociale fordelingsprincip (forskelsprincippet) „,in censure of the self-seeking choices of high-flying marketeers, choices which induce an inequality that ... is harmful to the badly off“. Dette betyder også, at Rawls ikke gør op med incitamentsargumentet, hvilket Cohen mener, at der er gode grunde til at gøre. Cohen (2008, kap. 1) sætter derfor som mål „rescuing justice from the incentives argument“. Påvisningen af, at incitamentsargumentet er uholdbart, er en vigtig del af muligheden for at begrunde en mere ligelig fordeling af samfundets ressourcer.

\section{Kritikken af incitamentsargumentet}

I den offentlige debat møder venstreorienterede ofte den indsigelse, at en mere lige fordeling af goderne ville underminere motivationen til at arbejde og gøre en ekstra indsats. I tillæg til denne præmis, som er den første præmis i incitamentsargumentet, hævdes det ofte, at økonomiske incitamenter til at gøre en ekstra indsats vil være til alle samfundsmedlemmers gavn. Herefter kan der sættes trumf på argumentet imod lighed ved at konkludere, at hvis man bekymrer sig de om de svagestes kår (som venstreorienterede gør), burde man acceptere økonomiske incitamenter og ulighed. Hvis dette incitamentsargument er holdbart, har venstreorienterede, der ønsker de bedst mulige vilkår for de dårligst stillede, et problem. Den lighed, de kæmper for, ser ud til at ville stille de svageste eller mindst begunstigede (og alle andre) værre, end de ellers kunne have været stillet.

Venstreorienterede har ofte svært ved at give et adækvat svar på incitamentsargumentet. Det er derfor, Rawls formulerer sit forskelsprincip på en måde, som tillader ulighedsskabende incitamenter, hvis og når det kan vises, at disse er til fordel for de mindst begunstigede i samfundet. Man skal bare være opmærksom på, at incitamentsargumentet bygger på en præmis om, at borgerne i deres private valg eller som markedsaktører er drevet af egeninteresse. Det er kun, hvis man accepterer denne præmis, 
at incitamentsargumentet kan "get off the ground“. For det er helt grundlæggende for incitamentsargumentets succes, at vi godtager, at folk kun vil arbejde, hvis de får mere end dem, der ikke arbejder, eller at de kun vil gøre en ekstra indsats, hvis de får mere end dem, der ikke yder en ekstra indsats. Derudover indebærer incitamentsargumentet, at man ikke kan kritisere folk for at kræve mere for at arbejde eller gøre en ekstra indsats end for ikke at gøre det. Men det sidste har venstrefløjstænkere, der afviser moraliseren i snæver forstand, vel også accepteret. De affinder sig med, at de kun kan kritisere systemet (eller hos Rawls den grundlæggende struktur), og at de ikke kan klandre borgerne for at være motiveret af og vælge på baggrund af egoistiske økonomiske hensyn. Dette er en stor fejltagelse ifølge Cohen.

Det er vigtigt at være opmærksom på, at Cohen kun vurderer incitamentsargumentet som et argument, der accepterer, at fordelingen af goderne i samfundet skal være til størst mulig gavn for de mindst begunstigede. Han vurderer altså for eksempel ikke i denne sammenhæng argumenter for ulighed, der er baseret på, at økonomiske incitamenter skal gives på baggrund af, hvem der fortjener dem. Incitamentsargumentet skal ikke blandes sammen med det argument, at de der arbejder eller gør en ekstra indsats, har fortjent en større andel af goderne end dem, der ikke arbejder eller ikke yder noget ekstra. Men ikke bare Rawls, men også mange på den politiske hørefløj bruger faktisk det argument, at økonomiske incitamenter til de arbejdssomme og produktive også løfter de svage. Incitamentsargumentet, som vi vurderer det her, er altså baseret på den normative præmis, at økonomiske uligheder er retfærdige, fordi de stiller de mindst begunstige bedre end en mere lige fordeling af goderne.

Vi kan lægge ud med at sætte spørgsmålstegn ved den præmis i incitamentsargumentet, der siger, at økonomiske incitamenter er nødvendige for at få de arbejdsduelige til at arbejde og de talentfulde til at udnytte deres talenter. Kan man virkelig sige, at økonomiske incitamenter er nødvendige? De er næppe nødvendige i streng forstand, dvs. på den måde som mad og drikke er nødvendige. Det er ikke muligt for nogen mennesker at leve uden mad og drikke, men det er muligt for dem, incitamenter er rettet mod, at tage et arbejde, uden at det kan betale sig ift. at være på kontanthjælp, og det er muligt at gøre en ekstra indsats uden at få mere end dem, der ikke gør en ekstra indsats. Faktisk bygger incitamentsargumentet på en forudsætning om, at det er muligt at valge, om man vil arbejde og gøre en ekstra indsats eller ikke (incitamentsargumentet kan i sin natur kun være rettet mod de arbejdsduelige). Økonomiske incitamenter handler jo om at få folk til at tage de rigtige valg - nemlig at arbejde og være produktive til gavn for samfundet som helhed. At det ikke kan være en streng nødvendighed at give borgerne incitamenter, er den først præmis i Cohens (immanente) kritik af incitamentsargumentet. Om man arbejder eller ikke, og om man gør en ekstra indsats eller ej, er et spørgsmål om menneskelig vilje og valg.

Hvis ulighedsskabende incitamenter begrundes med, at de er til de dårligst stilledes bedste, og hvis Cohen har ret $\mathrm{i}$, at det ikke er en streng nødvendighed for at være produktiv, at man får mere end andre, så opstår der en oplagt respons til dem, der kræver mere end andre for at være produktive eller gøre en ekstra indsats (Cohen 2008, 27ff). 'Hvis I er interesseret i, at de dårligst stillede får det så godt som muligt, som I påstår, hvorfor vælger I så at kræve mere end andre for at være produktive? Hvorfor arbejder I ikke bare hårdere uden at få mere end andre, hvilket ville stille de dårligst stillede endnu bedre?' Hvordan kan de, der fremfører incitamentsargumentet, forsvare sig imod denne indvending? Det virker oplagt, at Cohen har ret $\mathrm{i}$, at de dårligst stillede ville blive endnu bedre stillede, hvis de produktive og talentfulde valgte at være produktive og udnytte deres talenter uden at kræve ulighedsskabende incitamenter. Der er derfor kun to muligheder for tilhængerne af incitamentsargumentet: enten må de benægte, at målet er, at de dårligst stillede får det så godt som muligt, eller også må de afvise præmissen om, at det er muligt at vælge, om man arbejder eller ej, gør en ekstra indsats eller ej. Begge disse muligheder forekommer mig dog at underminere noget helt centralt ved incitamentsargumentet.

Bemærk, at Cohens kritik af incitamentsargumentet ikke er henvendt til dem, der ikke forsvarer ulighed med, at de dårligst stillede ville have det værre under en mere lige fordeling af goderne. Cohens argument bider kun på personer, der mener, at et retfærdigt samfund er et samfund, hvor uligheder kun kan forsvares, hvis de er til størst mulig gavn for de dårligst stillede. Dette gælder blandt andet dem, der accepterer Rawls' forskelsprincip. Problemet for Rawls er imidlertid, at ulighedsskabende incitamenter kun kan begrundes i et samfund, hvor borgerne ikke er guidet af forskelsprincippet. Hvis borgerne var guidet af forskelsprincippet, ville de vælge at handle på en måde, som forbedrede de dårligst stilledes kår, hvilket udelukker krav om at få mere for at yde en ekstra indsats. Som Cohen skriver (2008, 32): "The difference principle can be used to justify paying incentives that induce inequalities only when the attitude of talented people runs counter to the spirit of the difference principle itself: they would not need special incentives if they were themselves unambivalently committed to the principle." Cohen konkluderer på denne baggrund, at forskelsprincippet ikke kan anvendes til at forsvare incitamenter, der skaber uligheder. Cohens argument er ikke kun relevant 
som en filosofisk kritik af Rawls, det rækker videre til alle dem i den offentlige debat, der forsvarer ulighed med henvisning til, at det er til de dårligst stilledes eget bedste, at de mere arbejdsomme, produktive og talentfulde får mere, end de dårligst stillede selv gør.

\section{Systemkritik og egalitært etos}

Venstrefløjen kan ikke begrænse sig til systemkritik, hvis den vil indoptage ovenstående kritik af incitamentsargumentet. Ifølge Cohen bør venstrefløjen blankt afvise det forsvar for ulighed, der siger, at det er nødvendigt at give mere til nogle end andre for at skabe produktiv flid, og at dette er til alles gavn. Venstrefløjen bør kritisere den egoisme og grådighed, der gør, at nogle kræver (og får) mere end andre - nogle ekstremt meget mere andre - for at yde en ekstra indsats. Betyder det, at venstrefløjen skal moralisere? Det gør det, hvis man med moralisere mener at fremsætte argumenter, der underlægger borgernes personlige valg retfærdighedsprincippernes kritiske lys. Cohens argument skal vise, at retfærdighedsprincipperne ikke kun bør gælde samfundets grundlæggende struktur (som hos Rawls), men også børe være rettet mod borgernes personlige valg. Hvis vi ikke retter kritikken mod de personlige valg, er der en fare for, at vi undskylder og fremmer den menneskelige egoisme.

Ifølge Cohen er den eneste måde ,at rede ligheden fra incitamentsargumentet" at rette de kritiske skyts og retfærdighedsprincipperne mod de personlige valg, borgerne tager. Dette argument hos Cohen viser, at for at skabe et mere lige samfund er det ikke tilstrækkeligt at revolutionere samfundets økonomiske struktur, der er også behov for en revolution i menneskers følelser og motivation (Cohen 2000, 119f). Der er med Cohens ord behov for et mere egalitært etos, dvs. en mentalitet, der får borgerne til frit (dvs. uden tvang og materielle incitamenter) at vælge at handle på en måde, som forbedrer de dårligst stilledes vilkår. „In the absence of such an ethos, inequalities will obtain that are not necessary to enhance the condition of the worst off: the required ethos promotes a distribution more just than what the rules of the economic game by themselves can secure" (Cohen 2000, 128). Et egalitært etos vil skabe en mere lige (for Cohen retfærdig) fordeling af goderne, fordi borgerne vil vælge at bidrage på en måde, som er til alles bedste, uden at kræve ulighedsskabende incitamenter for at gøre dette.

Når venstrefløjen adskiller systemkritik og diskussion af markedsaktørers valg, er der ifølge Cohen en fare for, at den accepterer den menneskeforståelse, som kapitalismen har bragt med sig. Grådighed og frygt er de dominerende motiver på markedet, da andre mennesker ses „as possible sources of enrichment, and as threats to one's success. These are horrible ways of seeing other people, however much we have become habituated and inured to them, as a result of centuries of capitalist civilization" (Cohen 2009, 40f). Pointen her er ikke, at det kapitalistiske marked med dets egoistiske motiver ikke har vist sig at være effektivt. Pointen er heller ikke, at mennesker ikke ofte er drevet af egeninteresse. Pointen er derimod, at vi ikke skal forveksle effektivitet med retfærdighed og ikke bør undskylde den menneskelige egoisme, selv når den instrumentelt set fører til et effektivt marked (Cohen 2008, 114f). Som Cohen skriver, "we should never forget that greed and fear are repugnant motives" (Cohen 2009, 77). Venstrefløjen bør ikke glemme dette, da det kan føre til, at den stiller sig tilfreds med det samfund, vi har, og med den type markedsøkonomi, vi har. Det er rigtigt, at det endnu ikke er lykkedes at skabe et effektivt marked, som ikke bygger på egoisme, men det betyder ikke, at det ikke stadigvæk er værd at forsøge. Og vi kan kun forstå, hvorfor det er værd at forsøge, hvis vi forstår og kan begrunde, at et samfund, der bygger på grådighed og frygt, er et frygteligt samfund. Cohen $(20009,82)$ slutter således sin lille bog Why Not Socialism? med at citere Albert Einstein for, at socialismen er menneskehedens forsøg på at gå „hinsides den rovgriske fase i menneskets udvikling“, og tilføjer: „Our attempt to go beyond predation has thus far failed. I do not think the conclusion is to give up."

\section{Konklusion}

Den danske venstrefløj vakler i disse år mellem hensynet til arbejderne på den ene side og hensynet til dem uden for arbejdsmarkedet på den anden side. Det er i denne artikel blevet argumenteret for, at normativ politisk teori kan bidrage til at forstå denne ambivalens. Man skal dog ikke tro, at den politiske teori kan give os endegyldige svar på, hvad der de rigtige valg at tage politisk. De normative principper, som den politiske teori kan bidrage til at klargøre og begrunde, kan kun være ét element i den offentlige debat. Det spinkle håb for venstreorienterede politiske teoretikere er, at retfærdighedsprincipper i det mindste bliver et element i venstrefløjens selvrefleksion og debat. Det særlige ved Cohens teori er, at disse principper ikke blot bør rettes mod systemet eller samfundets grundlæggende struktur, men også mod borgernes private valg. Man kan sige, at de stigende krav til de arbejdsløse, som vi oplever i dag fra S-R-SF-regeringens side, er et tegn på, at venstrefløjen i dag ikke blot ser på strukturerne, men også moraliserer i snæver forstand. Men med Cohens kritik af incitamentsargumentet in mente kunne man indvende, at venstrefløjen nærmere burde rette sin moralske kritik mod dem, der kræver at få mere end andre for at være produktive og udnytte deres talenter. 


\section{Referencer}

Cohen, G.A. 2000, If You are an Egalitarian, How Come You Are So Rich?, Harvard University Press, MA, Cambridge.

Cohen, G.A. 2008, Rescuing Justice and Equality, Harvard University Press, MA, Cambridge.

Cohen, G.A. 2009, Why Not Socialism? Princeton University Press, Princeton.

Geras, N. 1985, 'The Controversy About Marx and Justice', New Left Review vol. 150, pp. 47-85.

Geras, N. 1992, 'Bringing Marx to Justice: An Addendum and Rejoinder', New Left Review vol. 195, pp. 37-69.

Habermas. J. 2009, 'Afterword: Lessons of the Financial Crisis', i J. Habermas, Europe: The Faltering Project, Polity, Cambridge.

Jespersen, P.M. 2012, '„Regerings krisepolitik er stupid“', Interview med Preben Wilhelm, Politiken 25/08/12.

Marx, K. 1962 [1844], 'Om jødespørgsmålet', i K. Marx, Økonomi og filosofi. Ungdomsskrifter, Gyldendal, København.

Marx, K. 1990 [1867], Capital Vol 1, Penguin, London.

Marx, K. 2000 [1845/46]. 'Den tyske ideologi', i K. Marx, De store tenkere - Karl Marx. Rosinante, København.

Pedersen, T.M. 2012, 'En skattereform til dem der trækker læsset', kommentar i Berlingske, 17/01/12, http://www.b.dk/kommentarer/ en-skattereform-til-dem-der-traekker-laesset

Rawls, J. 1999, A Theory of Justice, Revised Edition, Harvard University Press, MA, Cambridge.

Rawls. J. 2005. En teori om retfardighed, rev. udg., oversat af M.C. Jacobsen, Det lille Forlag, København.
Roemer, J. (ed.) 1986, Analytical Marxism, Cambridge University Press, Cambridge.

Rostbøll, C.F. 2011, Jürgen Habermas, Jurist- og Økonomforbundets Forlag, København.

Skovhus, D. 2012, 'Er Thor Möger bannerfører for de hårdtarbejdende?', kommentar i Politiken, d. 28/01/12, http://politiken.dk/ debat/profiler/skovhus/ECE1521903/er-thor-mger-bannerfoererfor-de-haardtarbejdende/

Smith, A. 2000, The Wealth of Nations, The Modern Library, New York. Wolff, J. 2012, 'Equality and Justice', i C. McKinnon (ed.), Issues in Political Theory, 2. edn., Oxford University Press, Oxford.

Wood, A. 1972, 'The Marxian Critique of Justice', Philosophy \& Public Affairs vol. 1, no. 3, pp. 244-282.

\section{Noter}

1. Bl.a. i DR2's Deadline d. 30/11/11.

2. Naturligvis kan venstrefløjens udmeldinger være en konsekvens af strategi frem for overbevisning, men jeg antager, at udmeldingerne stikker dybere end blot et ønske om at tækkes vælgerne.

3. Min bevæggrund for at trække denne relation er, at hele den danske venstrefløj er påvirket af Marx og marxismen. Hvor stor indflydelse marxismen har på de nuværende venstrefløjspartier og -bevægelser, varierer naturligvis. Pointen i teksten er, at mennesker på venstrefløjen bør reflektere over, hvor meget marxistisk baggage de bærer på, og hvad dette betyder for deres ideologi og stillingtagen. 